\title{
Antioxidant, Anti-inflammatory, Antiproliferative and Antimicrobial Activities of Combretum glutinosum and Gardenia aqualla Extracts in vitro
}

\author{
Bawa Yusuf Muhammad ${ }^{1,2}$, , Nadia Zaky Shaban ${ }^{1}$, Fatima Hassan Elrashidy ${ }^{1}$, Doaa Ahmed Ghareeb ${ }^{1,3}$
}

\section{Bawa Yusuf \\ Muhammad $^{1,2, *}$, Nadia Zaky Shaban ${ }^{1}$, Fatima Hassan Elrashidy ${ }^{1}$, Doaa Ahmed Ghareeb $b^{1,3}$ \\ 'Department of Biochemistry, Faculty of Science, Alexandria University, Alexandria, EGYPT. \\ 'Department of Biochemistry and Molecular Biology, Faculty of Science, Nasarawa State University Keffi, NIGERIA. \\ ${ }^{3}$ Bioanalytical centres of Excellence: Phar- maceutical and fermentation Department, GEBRI, SRAT-city, Alexandria, EGYPT. \\ Correspondence \\ Dr. Muhammad Bawa Yusuf}

'Department of Biochemistry, Faculty of Science, Alexandria University, Alexandria-21500, EGYPT.

2Department of Biochemistry and Molecular Biology, Faculty of Science, Nasarawa State University Keffi, NIGERIA Phone no: +234 8067799807

E-mail: rabbanimuhammad1@gmail.com History

- Submission Date: 07-09-2019;

- Review completed: 09-09-2019;

- Accepted Date: 05-10-2019.

DOI : 10.5530/fra.2019.2.12

Article Available online

http://www.antiox.org

Copyright

(C) 2019 Phcog.Net. This is an openaccess article distributed under the terms of the Creative Commons Attribution 4.0 International license.

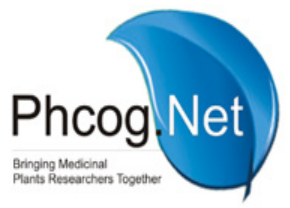

\begin{abstract}
Objectives: Plants represent a diverse template that could be tapped as sources of novel drugs. This study highlights antioxidant, anti-inflammatory, anti-proliferative and as well antimicrobial activities of Combretum glutinosum (BE) and Gardenia aqualla (GE) roots ethanol extracts. Methods: The Biological activities were evaluated using the established standard methods. Results: Both extracts exhibited antioxidant and anti-inflammatory activities with BE being better than GE. Anti-proliferative (cytotoxicity) assay on HepG2 and BHK-21 cell lines similarly revealed that $\mathrm{BE}\left(\mathrm{IC}_{50}: 55, \mathrm{SI}: 1.81\right)$ is more cytotoxic and more selective than $\mathrm{GE}$ $\left(\mathrm{IC}_{50}: 478.60, \mathrm{SI}: 0.99\right)$. For the antimicrobial study, BE inhibited the growth of pathogenic bacteria; Pseudomonas aeruginosa, Staphylococcus aureus, Vibrio species and E. coli, while GE extract showed activity against Candida albicans. Conclusion: We conclude that Combretum glutinosum extract (BE) possessed the most robust activity from this study. Hence, it could be a promising source of novel drug with wide biological activities, especially antioxidant and anticancer activities.
\end{abstract}

Key words: Antioxidant, Cytotoxicity, Cancer cell line, Anti-microbial, Drug discovery.

\section{INTRODUCTION}

Medicinal plants contain secondary metabolites, some of which have the capacity to prevent or treat many pathological conditions. These secondary metabolites could inhibit or modulate inflammatory response and oxidative Stress (O.S.); which in turn, could prevent or treat pathological conditions. ${ }^{1}$ Free Radicals (F.R.) are fundamental to any biochemical process and represent an essential part of aerobic life and metabolism. ${ }^{2}$ FRs include Reactive Oxygen Species (ROs) and Reactive Nitrogen species (RNs). The most common ROs include: Superoxide anion radical $\left(\mathrm{O}_{2}^{-}\right)$, hydrogen peroxide $\left(\mathrm{H}_{2} \mathrm{O}_{2}\right)$, peroxy radical $\left(\mathrm{ROO}^{-}\right)$and reactive hydroxyl $\left(\mathrm{OH}^{-}\right)$radicals while RNs include: nitric oxide (NO) and peroxy nitrite anion. ${ }^{2,3}$ Under normal circumstances, homeostasis exists between FRs generated in the body and antioxidants available to scavenge them. However, a shift in this balance causes O.S. which could cause inflammation, tissue injury DNA-damage, increased mutation rate within cells and thus promoting oncogenic transformation. ${ }^{1}$ In addition, O.S. can trigger signalling pathways hence contribute to tumour development through regulation of cellular proliferation, angiogenesis and metastasis. ${ }^{3}$ Antioxidant offers resistance against O.S. by scavenging F. R, inhibiting Lipid Peroxidation (LPO) and prevent damage to proteins and nucleic acids thus, preventing disease progression. ${ }^{4}$ Antioxidants include both enzymatic such as Superoxide Dismutase (SOD), Glutathione Peroxidase $(\mathrm{GPx})$, catalase, glutathione reductase and non-enzymatic such as glutathione, Vitamins $\mathrm{A}, \mathrm{C}$ and among others. ${ }^{5} \mathrm{On}$ the other hand, increasing incidence of drug-resistance, adverse effect and toxicity has stimulated the effort of scientists and pharmaceutical industries to search for drugs from natural sources. ${ }^{6}$ Out of 109 new antibacterial drugs, approved in the period 1981-2006, 69\% got their root from medicinal plants and other natural compounds and $21 \%$ of antifungal drugs were natural derivatives or compounds mimicking natural products. ${ }^{7}$ Nigeria is a country that is blessed with vast arrays of flora most of which are yet to be discovered and utilized maximally in biomedical research, to arrive at a drug. Some of these flora used in Nigerian traditional medicine include; Combretum Spp and Gardenia aqualla among others.

The Combretum glutinosum (Hausa name: Baushe; $B$ ), belongs to the family Combretaceae consisting of 20 genera with at least 600 species. In West Africa C. glutinosum is used as an important source of yellow to brownish dye for cotton textiles beside it medicinal purposes. Many species of Combretum (Combretaceae) have been used as traditional medicines for many applications, including abdominal disorders, bacterial infections, diarrhea, bilharzias, malaria, respiratory infections, pneumonia, skin and 
venereal diseases, fevers and sore throats, liver, kidney complains and cancer especially. ${ }^{8}$ Gardenia aqualla (Hausa name: Gaude; G). a shrub plant of Rubeacea family, grows up to 3 metres high in the savannah; found in Senegal, Nigeria Sudan and other west African countries. Medicinally the leaf is used to treat leprosy, the root to treat oral infections, the fruit for ear infection and the stem bark is used to treat bowel disorders. ${ }^{9}$ These plants are very important from the pharmaceutical point of view; therefore, present study was carried out to investigate; the anti-oxidant, anti-inflammatory, anti-proliferative (anticancer activity) as well as anti-microbial activities of their ethanol extract.

\section{MATERIALS AND METHODS}

\section{Chemicals}

Trichloro Acetic Acid (TCA), Thiobarbituric Acid (TBA), Butylated Hydroxytoluen (BHT), 1,1-diphenyl-2picryl hydrazyl (DPPH) radical, p-nitrophenyl-b-D-glucopyranoside (PNPG), 5,5'-dithiobis 2-nitrobenzoic acid (DTNB), napthylenediamine hydrochloride, sulphanilamide, 3-[4,5-dimethylthiazole-2-yl]-2,5-diphenyltetrazolium bromide (MTT) and sodium nitroprusside were purchased from Sigma Chemical Co. (St. Louis, Mo, USA). Organic solvents of HPLC-grade ethanol 95\% were obtained from Merck (USA). All other chemicals and reagents were of analytical grade.

\section{Collection and extraction of plant samples}

Plants samples (which include the roots, leaves and fruits) were collected in January 2015 from Keffi, Nasarawa State, Nigeria. The roots were authenticated at the Department of plant science and Biotechnology, Nasarawa State University, Keffi and Voucher specimens were deposited at the herbarium. The roots were washed with water, cut into pieces, grinded with pestle and mortar then allowed to dry in the shade. A small mesh sieve was used to obtain small particles of about $100 \mu \mathrm{m}$. The larger particles were discarded while the powdered kept in air tight plastic container until further use. The dried powdered root of each plant (100g) was exhaustively defatted with petroleum ether then soaked in $300 \mathrm{ml}$ ethanol (95\%) and left for $48 \mathrm{hr}$. The extracts were obtained by filtration, then concentrated using rotary evaporator at $55^{\circ} \mathrm{C}$ and $100 \mathrm{rpm}$ (BÜchi, Switzerland) then lyophilized (DISHI, DS-FD-SH10, Xian Heb Biotechnology Co, China) to obtain extracts in powdered form. The extracts were kept at $-20^{\circ} \mathrm{C}$ until used.

\section{Human Blood}

Human participants and their specimen (blood) met the ethical standards for donor agreement, made mandatory by national regulatory bodies. Participants signed informed consent for the use of their blood in this study. Blood samples ( $2 \mathrm{ml}$ each) were collected from five healthy individuals who did not take any medication two weeks prior to collection.

\section{Animals}

Experimental procedure was approved by Alexandria University Animal Ethics Committee (AEC) and animals received tender care as contained in the guide lines of National Health and Medical Research Council (NHMRC), Arab Republic of Egypt. Six male rats (150-200g body weight) were obtained from animal house of medical research institute, Alexandria University (Egypt). Animals were left to adapt to our laboratory for two weeks before the experiment. The livers were harvested from the animals under anaesthesia and washed in cold saline, then one gram of each liver was homogenized in $9 \mathrm{ml}$ phosphate buffer saline. The homogenate was centrifuged at 3000 and metabolites containing supernatant was carefully decanted for further biochemical assessments.

\section{Phytochemical composition}

Dried powdered plants root extracts were spectrophotometrically screened for total phenolic and flavonoids. The Folin-ciocalteu reagent method as described by Demiray et al. ${ }^{10}$ was employed to determine the total phenolic contents of the plant extracts. While Aluminium chloride colorimetric method was used for total flavonoids determination. ${ }^{5}$

\section{Assessment of antioxidant activities}

The anti-oxidant activities of the plants root extracts were determined by DPPH Radical Scavenging Assay (1,1-diphenyl-2picryl hydrazyl). ${ }^{11}$ The method of Halliwel et al. ${ }^{12}$ was used to assay HO. Nitric oxide scavenging activity was estimated using Griess reagent. ${ }^{13}$ The lipid peroxidation assay was carried out by a method modified and used by Ghareeb et al. ${ }^{14}$ Glutathione peroxidase (GPx) activity (EC NO:1.11.19) was determined by the method of Paglia and Valentia. ${ }^{15}$ and Determination of superoxide dismutase (SOD) activity (EC NO:1.15.1.1) by the method of Markland and Marklund. ${ }^{16}$

\section{Assessment of in vitro anti-inflammatory activity}

Inhibition of albumin denaturation and Membrane stabilization test were used to test for anti-inflammatory activity. ${ }^{17}$

\section{Antimicrobial assay}

The indicator bacteria used in current investigation were Pseudomonas aeruginosa ATCC: 8739, Staphylococcus aureus ATCC: 6538, Escherichia coli ATCC 8739 and Vibrio sp. The assay was carried out as described by Nassir et al..$^{18}$ and anti-fungal activity of the samples was determined by disk diffusion method on Muller Hinton agar (MHA) medium. ${ }^{19}$

Cytotoxicity assay by 3-[4,5-dimethylthiazole-2-yl]-2,5diphenyltetrazolium bromide (MTT)

Exponentially growing cells were trypsinized, counted and seeded at the appropriate densities (5000 cells $/ 0.33 \mathrm{~cm}^{2}$ well) into 96 -well microtiter plates. Cells were incubated in a humidified atmosphere at $37^{\circ} \mathrm{C}$ for 24 hrs. Then cells were exposed to the two extracts, at the desired concentrations $(0.1,1,10,100$ and $1000 \mu \mathrm{g} / \mathrm{ml})$ for $72 \mathrm{hrs}$. At the end of the treatment period, media were removed, cells were incubated with $200 \mu \mathrm{l}$ of 5\% MTT solution/well (Sigma Aldrich, MO) and allowed to metabolize the dye into a coloured-insoluble formazan complex for $2 \mathrm{hrs}$. Medium was discarded from the wells and the formazan crystals were dissolved in $200 \mu \mathrm{l} /$ well acidified isopropanol for $30 \mathrm{~min}$, covered with aluminium foil and with continuous shaking using a MaxQ 2000 plate shaker (Thermo Fisher Scientific Inc, MI) at room temperature. Absorbance was measured at $570 \mathrm{~nm}$ using a SpectraMax plus Microplate Reader (Molecular Devices, CA). The cell viability was expressed relative to the untreated control cells. Human hepatocellular carcinoma (HepG-2) and baby hamster kidney cell line (BHK-21) were originally purchased from American type culture collection (ATCC, Wesel, Germany) and grown in the tissue culture lab of the Egyptian company for production of vaccines, sera and drugs (Vacsera, Giza, Egypt). The cells were transferred to our laboratory and maintained in Dulbecco Modified Eagle Medium (DMEM). Both were Supplemented with $1 \%$ of $100 \mathrm{mg} / \mathrm{ml}$ of streptomycin, 100 units/ml of penicillin and $10 \%$ of heat-inactivated fetal bovine serum (Invitrogen, Carlsbad, CA) at $37^{\circ} \mathrm{C}$ in humidified incubator containing $5 \% \mathrm{CO}_{2} \cdot{ }^{20,21}$

\section{Statistical analysis}

All data were expressed as mean \pm standard deviation (SD). The differences were statistically significant at $P<0.05$. Statistical analyses were carried out using primers of Biostatistics program $V_{5}$ for analysis of unpaired student $t$ - Test and one way (ANOVA). 


\section{RESULTS}

\section{Characterization of the plants extracts.}

\section{Total phenolic content}

The result shows that the total phenolic content in BE and GE are $70.61 \mathrm{mg}$ and $40.76 \mathrm{mg}$ per gram dry extract, as Gallic acid equivalent respectively.

HPLC analysis of polyphenolic compounds: The result expressed in $\mathrm{mg} / \mathrm{g}$ (Figure $1 \mathrm{a}$ and $\mathrm{b}$ ) shows that, BE contains; catechins $(24.12 \mathrm{mg})$, vanillic acid $(0.46 \mathrm{mg})$, epigallocatechin gallate $(0.28 \mathrm{mg})$, kaempferol $(0.0051 \mathrm{mg})$, rutin $(0.0018 \mathrm{mg})$, quercetin $(0.0084 \mathrm{mg})$, apigenin $(0.0073 \mathrm{mg})$ while GE contains; 2,5-dihydroxy benzoic acid $(25.52 \mathrm{mg})$, vanillic acid $(0.47 \mathrm{mg})$, salicylic acid $(0.0013 \mathrm{mg})$, ferulic acid $(0.069 \mathrm{mg})$, naringenin $(0.0082 \mathrm{mg})$ and rosmarinic aid $(0.0051 \mathrm{mg})$.

\section{Total flavonoids content}

The result shows that the total flavonoid content in BE and GE are $100.44 \mathrm{mg}$ and $0.51 \mathrm{mg}$ per dry extract as quercetin equivalent respectively.

\section{Free radical scavenging and antioxidant activity}

$\mathrm{DPPH}$

Figure $2 \mathrm{a}$ shows that BE and GE have DPPH scavenging activity and these activities increase in concentration dependent manner. It also shows that BE has better activity than GE.

\section{Hydroxyl radical scavenging activity}

Figure $2 \mathrm{~b}$ shows that $\mathrm{BE}$ and $\mathrm{GE}$ have $\mathrm{HO}$ - scavenging activity and these activities increase in concentration dependent manner. It also shows that BE has better activity than GE.

\section{Nitric oxide radical scavenging activity}

Figure $2 c$ shows that $\mathrm{BE}$ and GE have NO. scavenging activity and these activities increase in concentration dependent manner. It also shows that BE has better activity than GE.

\section{Inhibition of lipid peroxidation activity}

Figure $2 \mathrm{~d}$ shows that $\mathrm{BE}$ and $\mathrm{GE}$ have scavenging/antioxidant activity by impeding lipid peroxidation and these activities increase in concentration dependent manner. It also shows that BE has better activity than GE.

\section{Antioxidant activity}

SOD activity

Figure 3a shows that BE and GE cause significant activation in SOD activity and these activities increase in concentration dependent manner. It also shows that $\mathrm{BE}$ has better activity than GE

\section{GPx activity}

Figure $3 \mathrm{~b}$ shows that $\mathrm{BE}$ and GE cause significant activation in SOD activity and these activities increase in concentration dependent manner. It also shows that BE has better activity than GE.

\section{Anti-inflammatory activity}

\section{Inhibition of RBC haemolysis}

Figure 4a shows that BE and GE have activity against hypotonic solution induced RBC haemolysis and these activities increase in concentration dependent manner. It also shows that BE has better activity than GE.

\section{Inhibition of albumin denaturation}

Figure $4 \mathrm{~b}$ shows that $\mathrm{BE}$ and GE have activity against heat induced albumin denaturation and these activities increase in concentration dependent manner. It also shows that BE has better activity than GE

\section{Cytotoxicity assay against normal and cancerous cells lines}

Figure 5 shows the activity of BE against normal BHK-21 and HepG2 with an $\mathrm{IC}_{50}$ of $100 \mu \mathrm{g} / \mathrm{ml}$ and $55 \mu \mathrm{g} / \mathrm{ml}$ respectively; given a selectivity index of 1.81 . Whereas, GE revealed an $\mathrm{IC}_{50}$ of $478.00 \mu \mathrm{g} / \mathrm{ml}$ and 478.60 $\mu \mathrm{g} / \mathrm{ml}$ respectively; given a selectivity index of 0.99

\section{Antimicrobial activity}

The Effect of BE and GE on selected pathogens is described in the (Table 1). BE has activity against all the pathogens while GE has activity against only two.

\section{DISCUSSION}

The result of phytochemical analysis showed that the total phenolic content in BE and GE are $70.61 \mathrm{mg}$ and $40.76 \mathrm{mg}$ per g dry extract, as Gallic acid equivalent respectively. While total flavonoids are $100.44 \mathrm{mg}$ and $0.51 \mathrm{mg}$ per dry extract as quercetin equivalent respectively. HPLC analysis revealed both extracts especially BE being very rich in flavonoids. Previous phytochemical studies showed that BE contains sterols, triterpenes, flavonoids, saponins, coumarins and tannins. While TLC revealed the presence of Apigenin, Genistein, Rutin and quercetin. ${ }^{22}$ ROS are generally generated from aerobic metabolism in the mitochondria and microsomes as well as metabolism of xenobiotic. ${ }^{23}$ Oxidative stress results from the imbalance between ROS/RNS and antioxidants
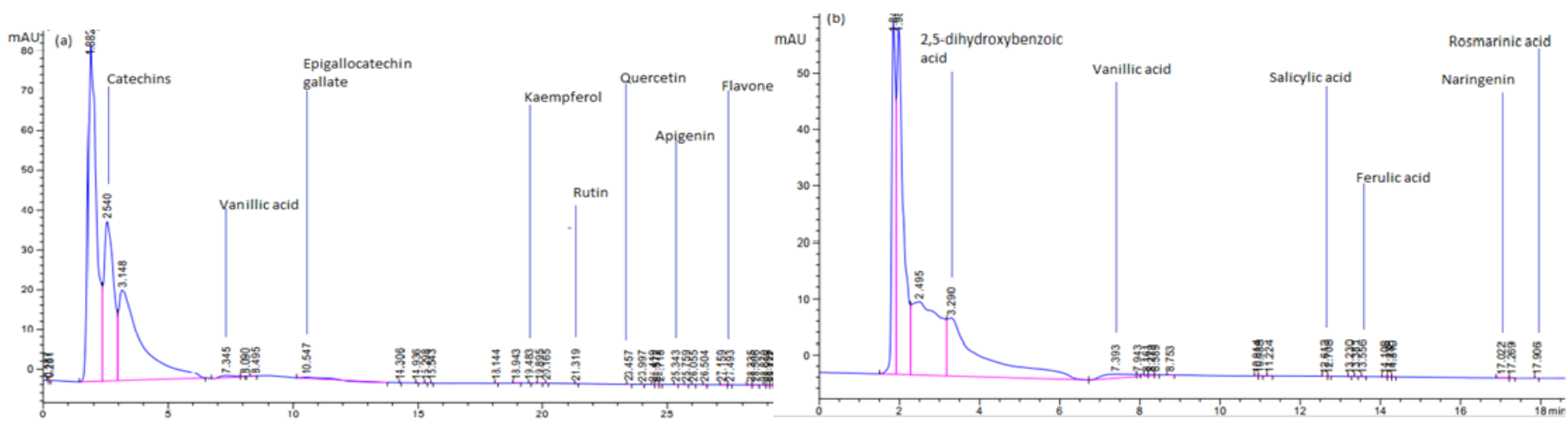

Figure 1: HPLC analysis of polyphenolic compounds present in studied plants. (A): Combretum glutinosum extract and (B): Gardenia aqualla extract. 
(A)

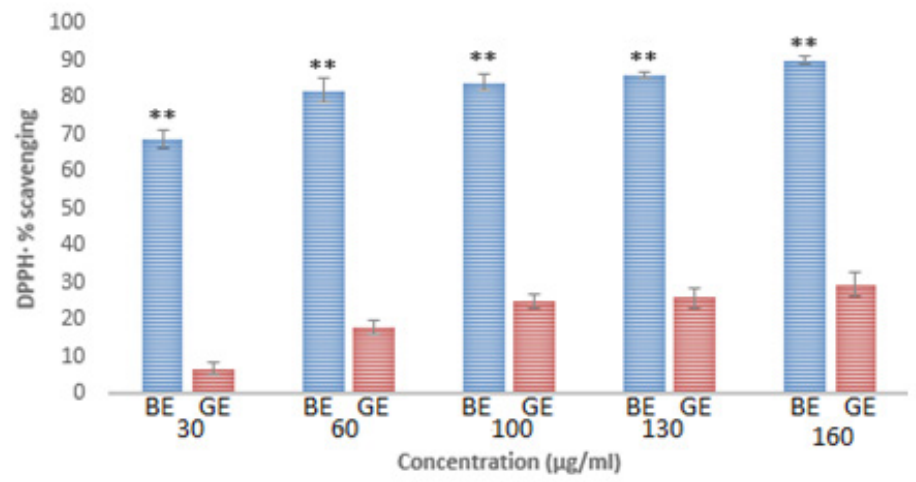

(C)

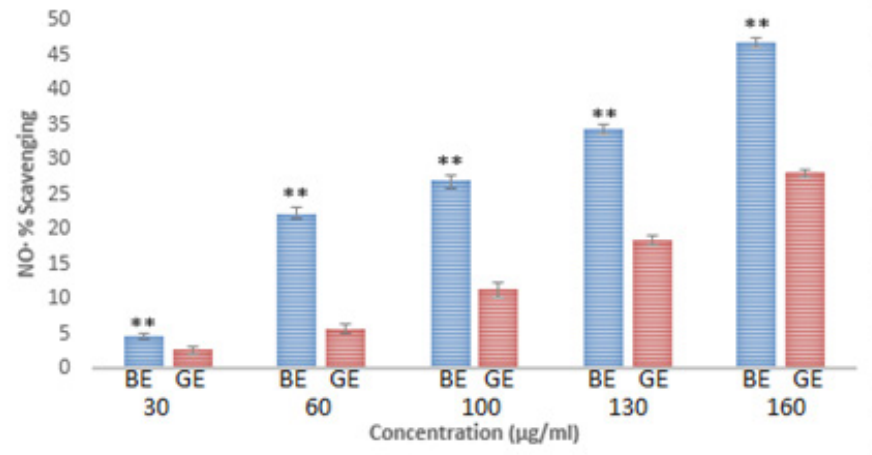

(B)

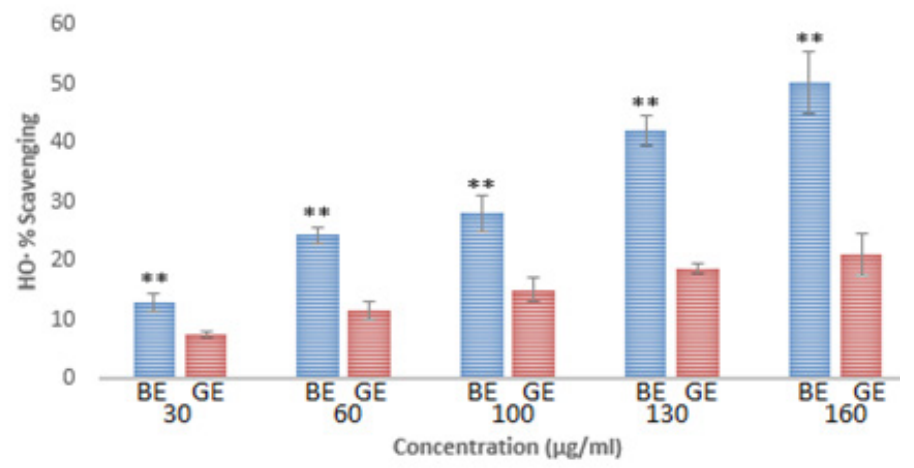

(D)

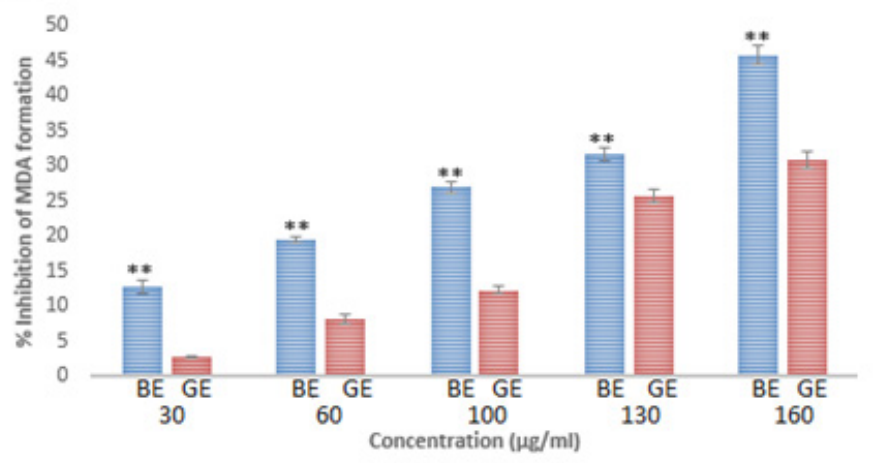

Figure 2: Radical scavenging effect of BE and GE. (A): DPPH (B) hydroxyl radical (C): Nitric oxide radical (D) Inhibition of MDA formation. Where BE: Combretum glutinosum and GE: Gardenia aqualla. Data are presented as Mean \pm SD $(n=3)$, values differ within column significantly at ${ }^{* *} P<0.05$.

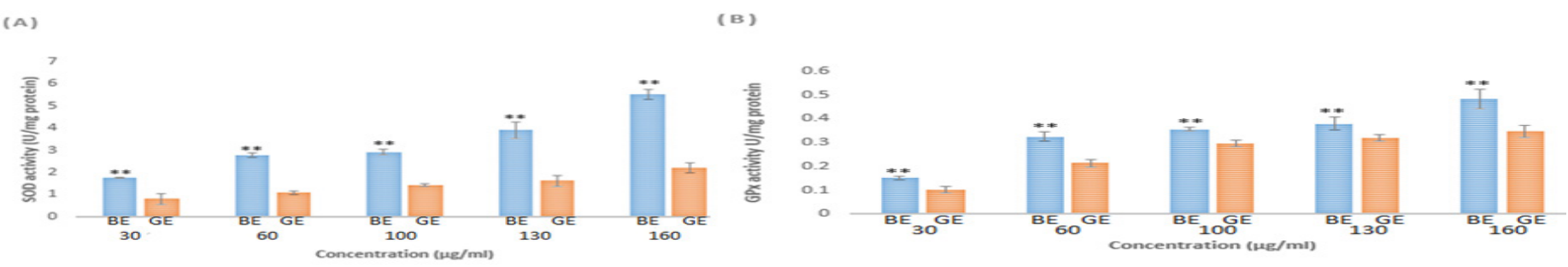

Figure 3: Effect of different concentrations of studied plants on some antioxidant enzymes activities in rat liver homogenate (A): Superoxide dismutase (SOD) and (B): Glutathione peroxidase (GPX). Where BE: Combretum glutinosum extract and GE: Gardenia aqualla extract Data are presented as Mean \pm SD ( $n=3$ ) values differ within column significantly at ${ }^{* *} \mathrm{P}<0.05$.

mechanisms of the body. ${ }^{24}$ Recently natural products are used as a source of pharmaceutical antioxidants. Therefore, in this study the antioxidant, anti-inflammatory, anticancer and antimicrobial activities of BE and GE were evaluated.

The result of this study showed that the $\mathrm{IC}_{50}$ of $\mathrm{BE}$ for $\mathrm{DPPH}, \mathrm{HO} \cdot \mathrm{NO}$. are $22 \pm 1.3 \mu \mathrm{g} / \mathrm{ml}, 160 \pm 0.8 \mu \mathrm{g} / \mathrm{ml}$ and $360 \pm 2.8 \mu \mathrm{g} / \mathrm{ml}$ respectively while GE are $271 \pm 2.1 \mu \mathrm{g} / \mathrm{ml}, 235 \pm 1.6 \mu \mathrm{g} / \mathrm{ml}$ and $432 \pm 3.8 \mu \mathrm{g} / \mathrm{ml}$ respectively. This indicates that $\mathrm{BE}$ has better scavenging activities for the various radicals than GE. These activities increased with increase in concentrations of the extracts. Similarly, BE and GE inhibited TBA-MDA adduct formation ex vivo. These activities could be because of the polyphenols and flavonoids found in these extracts. Compounds such as quercetin, kaempferol, catechins and apigenin identified in BE has been found to possess free radical scavenging and antioxidant activity. ${ }^{14}$ These could explain also why BE had greater activity compared to GE; since it contains higher concentrations of polyphenols and flavonoids than GE.
Table 1: The table describes the effect of BE and GE against selected microbial pathogens culture after $24 \mathrm{hrs}$.

\begin{tabular}{|c|c|c|}
\hline \multirow[t]{2}{*}{ Pathogens } & \multicolumn{2}{|c|}{$\begin{array}{c}\text { Extracts }(0.1 \mathrm{mg} / \mathrm{ml}) \text { and Zones of } \\
\text { inhibitions }(\mathrm{mm})\end{array}$} \\
\hline & $\mathrm{BE}$ & GE \\
\hline $\begin{array}{l}\text { Pseudononas } \\
\text { aeruginosa }\end{array}$ & 20 & -ve \\
\hline Staph. aureus & 26 & -ve \\
\hline Vibrio Sp. & 18 & -ve \\
\hline Candida albicans & 29 & 12 \\
\hline E. coli & 18 & 14 \\
\hline
\end{tabular}

BE has activity against all pathogens tested while GE has activity against two pathogens only. Where BE: Combretum glutinosum extract and GE: Gardenia aqualla extract. 
(A)

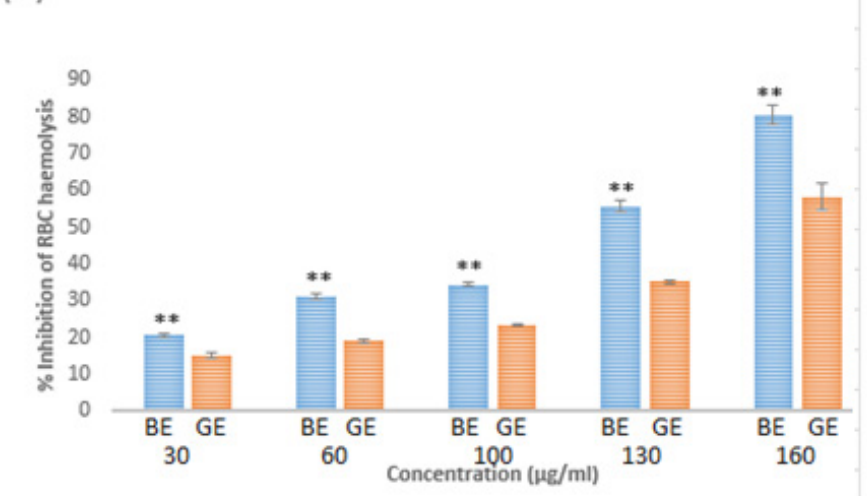

(B)

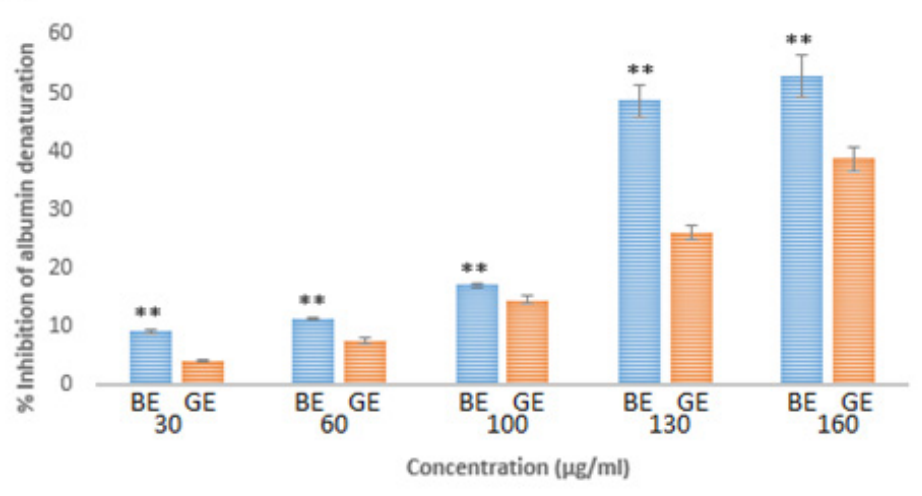

Figure 4: The anti-inflammatory activities of studied plants at different concentrations. (A): percentage inhibition of RBC haemolysis and (B): Percentage inhibition of albumin denaturation. Where BE: Combretum glutinosum extract and GE: Gardenia aqualla extract. Data are presented as Mean \pm SD $(n=3)$ values differ significant at $P^{* *}<0.05$.
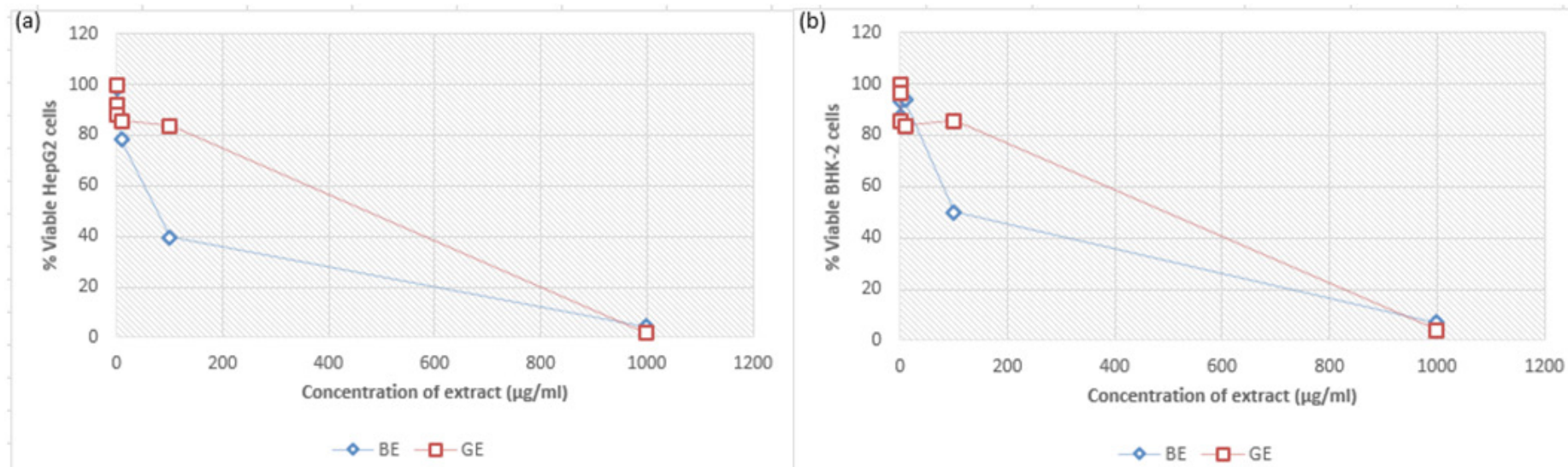

Figure 5: Effect of different concentrations of BE and GE on normal and cancer cells viability. (A): Activity HepG2 cells line and (B): Activity against BHK-21 cells line. Where BE: Combretum glutinosum extract and GE: Gardenia aqualla extract

In addition, the results showed that both $\mathrm{BE}$ and $\mathrm{GE}$ increased the activity of SOD and GPx in liver homogenate ex vivo. This activation was increased with increased concentrations of extracts. BE exhibited significantly $(P<0.05)$ greater activation of the enzymes activity compared to GE. These results agree to the previous studies which found that Polyphenols such as Quercetin, Kaempferol and resveratrol increase SOD, GPx and Catalase activity in vitro ${ }^{25}$ and in vivo. ${ }^{26,27}$ On the other hands, $\mathrm{BE}$ and GE inhibited HRBC haemolysis (with $\mathrm{IC}_{50} 117 \mu \mathrm{g} / \mathrm{ml}$ and $137 \mu \mathrm{g} / \mathrm{ml} \mathrm{respec}-$ tively) and heat induced albumin denaturation (with $\mathrm{IC}_{50} 151 \mu \mathrm{g} / \mathrm{ml}$ and $206 \mu \mathrm{g} / \mathrm{ml}$ respectively). Since cell membranes are similar in component and architecture, HRBC is therefore, like lysosomal membrane. For this reason, protection of $\mathrm{HRBC}$ membrane from lysis due to hypo tonicity and inhibition of heat induced albumin denaturation are considered as tests for anti-inflammatory activity. ${ }^{14,28}$ An inflammatory process resulting from infection and/or damaged tissues accompanied by the release of lysosomal enzymes (such as glycosidases, proteases and sulphases) and inflammatory mediators, is considered a hallmark for many pathological conditions; especially fibrosis and cancer. ${ }^{14,29}$ Nonsteroidal AntiInflammatory Drugs (NSAIDs) impede inflammation by either inhibiting lysosomal enzymes or by stabilizing the lysosomal membrane. ${ }^{14}$ For both RBC membrane stabilization and albumin denaturation assay, our extracts showed activity in concentration dependent manner. Likewise, NO. which could act as pro oxidant or an inflammatory mediator was found to be decreased by the extracts in concentration dependent manner (Figure 2 ) with $\mathrm{BE}$ having significantly $(P<0.05)$ higher activity. This suggests the possibility of BE to serve as possible pharmaceutical lead compound to isolate antioxidant, anti-inflammatory /or anticancer drugs.

In vitro cytotoxicity (MTT) assay against BHK-21 and HepG2 cell lines, revealed that Both $\mathrm{BE}$ and $\mathrm{GE}$ have an $\mathrm{IC}_{50}$ of less than $500 \mu \mathrm{g} / \mathrm{ml}$, hence considered cytotoxic. ${ }^{30} \mathrm{BE}$ showed higher activity against HepG2 ( $\mathrm{IC}_{50}$ : $55 \mu \mathrm{g} / \mathrm{ml}$ ) than BHK-21 cell line $\left(\mathrm{IC}_{50}: 100 \mu \mathrm{g} / \mathrm{ml}\right)$ and selectivity index (SI) of 1.81. Similar result was reported in some members of this genus. ${ }^{31}$ However, to the best of our knowledge this is the first finding on the ethanol root extract of this species against cancer cell line. On the other hand, GE indicated lower cytotoxicity $\left(\mathrm{IC}_{50}: 478.60 \mu \mathrm{g} / \mathrm{ml}\right.$ ) and S.I. of 0.99 this agrees to the findings of Tagne et al..$^{32}$ The variation in the cytotoxicity of BE and GE could be related to differences in their phytochemical compositions.

The result in Table 1 shows that plant BE has activity against all the pathogenic organisms tested, which agrees with the findings of Wimaluk et al. ${ }^{8}$ who found that BE has activity against all the pathogens tested including S. typhimurium and Kpneumoniae. On the other hand, GE has activity against Candida albicans and E. coli. This agrees to the findings of Suvarnalatta et al. ${ }^{33}$ 


\section{CONCLUSION}

This work establishes the potential of BE and GE as antioxidant, antiinflammatory, anticancer as well as antimicrobial agents. Follow up studies, in vivo testing and isolation of active compounds are recommended.

\section{ACKNOWLEDGEMENT}

The authors wish to acknowledge the contribution of Dr. Shymaa Abdulgaffar in the course of this research and Alexandria University for providing enabling atmosphere for the research.

\section{CONFLICT OF INTEREST}

The authors declare no conflict of interest.

\section{ABBREVIATIONS}

BE: Combretum glutinosum extract; GE: Gardenia aqualla extract; MTT: 3-[4,5-dimethylthiazole-2-yl]-2,5diphenyltetrazolium bromide; DPPH: (1,1-diphenyl-2picryl hydrazyl; BHK-21: Baby hamster kidney fibroblast cell line; HepG2: Human liver cancer cell line; NSAIDs: Nonsteroidal AntiInflammatory Drugs.

\section{REFERENCES}

1. Asowata-Ayodele AM, Otunola GA, Afolayan AJ. Assessment of the Polyphenolic Content, Free Radical Scavenging, Anti-inflammatory and Antimicrobial Activities of Acetone and Aqueous Extracts of Lippia javanica (Burm.F.) Spreng. Pharmacognosy Magazine. 2016:12(Suppl 3):S353-62. doi:10.4103/0973-1296.185770

2. Li S, Tan HY, Wang Z, Lixing L, Chi-Woon W, Yibin F. The Role of Oxidative Stress and Antioxidants in Liver Diseases. International Journal of Molecular Sciences. 2015;16(11):26087-124. doi:10.3390/ijms161125942

3. Kim-Shapiro DB, Gladwin MT. Mechanisms of Nitrite Bioactivation. Nitric Oxide: Biology and Chemistry/Official Journal of the Nitric Oxide Society. 2014;30:5868.doi: 10.1016/j.niox.2013.11.002

4. Alugoju P, Dinesh BJ, Latha P. Free Radicals: Properties, Sources, Targets and Their Implication in Various Diseases. Indian J Clin Biochem. 2015;30(1):1126. doi:10.1007/s12291-014-0446-0

5. Nadia ZS, Madiha HH, Mohamed AR, El-Kersh BF, Mahmoud A. Effects of Bacillus thuringiensis toxin on hepatic lipid peroxidation and free-radical scavengers in rats given alpha-tocopherol or acetylsalicylate. Comparative Biochemistry and Physiology Part C. 2003;135(4):405-14.

6. Roca I, Akova M, Baquero F, Carlet J, Cavaleri M, Coenen S, et al. The global threat of antimicrobial resistance: Science for intervention. New Microbes and New Infections. 2015;6:22-9. doi: 10.1016/j.nmni.2015.02.007

7. Dianella S. Plant-derived antimicrobial compounds: Alternatives to antibiotics. Future Microbiol. 2012;7(8):979-90. doi:10.2217/fmb.12.68

8. Wimaluk N, Chansakaow S, Putiyanan S, Natakankitkul N, Nantachit K, Khantawa B, et al. Chemical Constituents and Antibacterial Activity of Volatile Oils of Combretum latifolium BI. and C. quadrangulare Kurz Leaves. CMU J Nat Sci. 2015;14(3):245-56.

9. Burkill HM. The useful plants of west tropical Africa: Africa $2^{\text {nd }}$ edition. Botanical Garden Key. 1985;3:293-4

10. Demirat S, Pintado ME, Castro PML. Evaluation of phenolic profiles and antioxidant Activities of Turkish Medicinal Plants: Tilia argentea, Crataegi folium leaves and Polygonum bistort roots. World Acad Sci Eng Technol. 2009;54:312-7.s

11. Peihong FL, Terrier AE, Hay AM, Hostettmann K. Antioxidant and enzyme inhibitionactivities and chemical profiles of Polygonum sachalinensis F. Schmidt (Polygonaceae). Fitoterapia. 2010;81(2):124-31.

12. Halliwell BR, Aesc BR, Löliger J, Aruoma Ol. The characterization of antioxidants. Food and Chemical Toxicology. 1995;33(7):601-17.

13. Ebrahimzadeh MA, Nabavi SF, Nabavi SM. Antioxidant activities of methanol extract of Sambucus ebulus L. flower. Pakistan J Biol Sci. 2009;12(5):447-50.
14. Ghareeb DA, Amani EMD, Sheriff ME, Ashraf AS. In vitro screening for antiacylcholinesterase, antioxidant and anti-glucosidase, anti-inflammatory and anti-bacterial effect of the three-traditional medicinal plants. Biotechnology and Biotechnological Equipment. 2014;28(6):1155-64. http://dx.doi. org/10.1080/13102818.969877,

15. Panglia E, Valentine E. Studies on the quantitative and qualitative characterization of erythrocyte glutathione peroxidase. J Lab Clin Med. 1967;70(1):158-69.

16. Markland S, Marklund G. Involvement of the superoxide anion radical in the bio autoxidation of pyrogallol and convenient assay for superoxide dismutase. Eur J Biochem. 1974;47(3):469-74.

17. Mizushima $Y$, Kobayashi M. Interaction of anti-inflammatory drugs with serum Proteins, especially active proteins. J of Pharmacology. 1968;20(3):169-73.

18. Nasir B, Fatima H, Ahmed M, Haq IU. Recent trends and methods in antimicrobial drug discovery from plant sources. Austin J Microbiol. 2015;1(1):1-12.

19. Barani K. Manipal S, Prabu D, Ahmed A, Adusumili P, Jeevika C. Anti-fungal activity of Morinda citrifolia (noni) extracts against Candida albicans: An in vitro study. Indian J Dent Res. 2014;25(2):188-90

20. Mossman T. Rapid colorimetric assay for cellular growth and survival: Application to proliferation and cytotoxicity assays. Journal of Immunological Methods. 1983;65(1-2):55-63.

21. Scudiero DA, Shoemaker RH, Paull KD, Monks A, Tierney S, Nofziger $\mathrm{TH}$, et al. Evaluation of a soluble tetrazolium/formazan assay for cell growth and drug sensitivity in culture using human and other tumour cell lines. Cancer Res. 1988;48(17):4827-33

22. Alowanou GG, Olounlade AP, Azando EVB, Dedehou VFGN, Daga FD, Hounzangbeadote SM. A review of Bridelia ferruginea, Combretum glutinosum and Mitragina inermis plants used in zootherapeutic remedies in West Africa: Historical origins, current uses and implications for conservation. Journal of Applied Biosciences. 2015;87:8003-14.

23. Nadia ZS, Mohamed AR, El-Kersh FH, El-Rashidy NHH. Protective role of Punica granatum (pomegranate) peel and seed oil extracts on diethyl nitrosamine and phenobarbital-induced hepatic injury in male rats. Food Chemistry. 2013;141(3):1587-96.

24. Boufadi YM, Soubhye J, Riazi A, et al. Characterization and Antioxidant properties of Six Algerian Propolis extracts: Ethyl acetate inhibit Myeloperoxidase Activity. International Journal of Molecular Sciences. 2014;15(2):2327-45.

25. Molina MF, Sanchez-Reus I, Iglesias I, Benedi J. Quercetin: A flavonoid antioxidant, prevents andprotects against ethanol-induced oxidative stress in mouse liver. Biol Pharm Bull. 2003;26(10):1398-402.

26. Singh JP, Kaur A, Shevkani K, Singh N. Composition, bioactive compounds and antioxidant activity of common Indian fruits and vegetables. J Food Science Technol. 2016;53(11):4056-66. doi: 0.1007/s13197-016-2412-8

27. Nadia ZS, Mohamed AR, El-Kersh MM, Bader-Eldin SA, Kato AFH. Effect of Punica granatum (Pomegranate) Juice Extract on Healthy Liver and Hepatotoxicity Induced by Diethylnitrosamine and Phenobarbital in Male Rats. Journal of Medicinal Food. 2014;17(3):339-49. DOI: 10.1089/jmf.2012.0306

28. Shaikh RU, Pund MM, Gacche RN. Evaluation of anti-inflammatory activity of selected medicinal plants used in Indian traditional medication system in vitro as well as in vivo. Journal of Traditional and Complementary Medicine. 2016;6(4):355-61. http://doi.org/10.1016/j.jtcme.2015.07.001

29. Nabavi SM, Ebrahimzadeh MA, Nabavi SF, Hamidinia A, Bekhradnia AR. Determination of antioxidant activity, phenol and flavonoids content of Parrotia persica Mey. Pharmacology Online. 2008;2:560-7.

30. Prayong P, Barusrux S, Weera P. Cytotoxic activity screening of some indigenous Thai plants. Fitoterapia. 2008;79(7-8):598-601. 10.1016/j.fitote.2008.06.007

31. Gedson R, DeSales IRP, Marcelo RDCF, DeJesus NZT, DeSousa HF, Barbosa-Filho JM, et al. Bioactivities of the Genus Combretum (Combretaceae): A Review. Molecules. 2012;17(8):9142-206

32. Richard ST, Bruno PT, Nyemb JN, Didiane MY, Sylvain NN, et al. Anticancer and antioxidant activities of methanol extracts and fractions of some Cameroonian medicinal plants. Asian Pacific Journal of Asian Pac J Trop Med. 2014;7(1):S4427. doi: 10.1016/S1995-7645(14)60272-8.

33. Suvarnalatha A, Yasodamma N. Quantitative Phytochemical Evaluation of Indigofera hirsuta L. Plant Parts. International Journal of Pharma Research and Review. 2015;4(5):1-5 
GRAPHICAL ABSTRACT

\section{Both Extracts Are Rich In} Phenolics And Flavoniods:Have

\section{Antioxidant} activities; decreased MDAlevel and increased

SOD and GPX activities

Anti-inflammatory activities;inhibited RBC haemolysis and albumin denaturation
Anticancer activities; cytotoxic against BHk-21 and $\mathrm{HePG}_{2}$
Anti bacterial activities but GE has antifungal only.

\section{SUMMARY}

This study highlights antioxidant, anti-inflammatory, anti-proliferative and as well antimicrobial activities of Combretum glutinosum and Gardenia aqualla roots ethanol extracts. Both extracts exhibited antioxidant and anti-inflammatory activities, Anti-proliferative as well as antimicrobial activities invitro. We conclude that Combretum glutinosum extract possessed robust and wide biological activities, especially antioxidant and anticancer activities

\section{ABOUT AUTHORS}

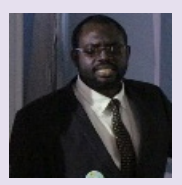

Muhammad Bawa Yusuf, Obtained PhD in Biochemistry (Molecular Therapeutics), from the Faculty of Science Alexandria University, Egypt and currently a lecturer at the Department of Biochemistry and Molecular Biology Nasarawa State University Keffi Nigeria. Have interest in studying Molecular Mechanism of Diseases.

Professor Nadia Zaky Shaban is a Professor of Biochemistry, Faculty of Science Alexandria University, Egypt.

Professor Doaa Ahmed Ghareeb is a Professor of Biochemistry (Molecular Therapeutics), Faculty of Science, Alexandria University, Egypt.

Dr. Fatima Hassan El-Rashidy is a lecturer of Biochemistry, Faculty of Science, Alexandria University, Egypt.

Cite this article: Muhammad BY, Shaban NZ, Elrashidy FH, Ghareeb AD. Anti-Oxidant, Anti-Inflammatory, Anti-Proliferative and Anti-Microbial Activities of Combretum glutinosum and Gardenia aqualla extracts in vitro. Free Radicals and Antioxidants. 2019;9(2):66-72. 